\title{
DIRASAH
}

Volume 3, Number 1, Februari 2020

p-ISSN: 2615-0212 | e-ISSN: 2621-2838

https://ejournal.iaifa.ac.id/index.php/dirasah

\begin{tabular}{|c|c|c|}
\hline Accepted: & Revised: & Published: \\
Nopember 2019 & Januari 2020 & Februari 2020 \\
\hline
\end{tabular}

\section{Pendidikan Akhlak Remaja Keluarga Muslim di Era Industri 4.0}

\author{
Partono \\ IAIN Kudus \\ e-mail : partono@iainkudus.ac.id
}

\begin{abstract}
The purpose of this study was to determine the role of parents and strategies in improving moral education in adolescents in Muslim families in the industrial era 4.0. The focus of this research problem is on how the concept of the role and strategies of adolescent moral education carried out by Muslim families in the industrial era 4.0. This type of research is a qualitative research with a descriptive qualitative approach. The results showed that parents' understanding of adolescent moral education is still very lacking, parental understanding of Islamic religion is still minimal so that adolescent ahklak education in Muslim households or families is very limited and the concept of family education for adolescents in moral education is to provide role models and provide knowledge of intolerance of intolerance to individual teenagers at home.
\end{abstract}

Keyword: Moral Education, Adolescent, Muslim Family, The Modern Era. 


\begin{abstract}
Abstraksi
Tujuan penelitian adalah guna mengetahui peran orang tua dan strategi dalam meningkatkan pendidikan akhlak pada remaja dalam keluarga muslim di era industri 4.0. Fokus masalah penelitian ini tentang bagaimana konsep peran dan strategi pendidikan akhlak remaja yang dilakukan oleh keluarga muslim di era industri 4.0. Jenis penelitian ini adalah penelitian kualitatif dengan pendekatan kualitatif deskriptif. Hasil penelitian menunjukan bahwa pemahaman orang tua terhadap pendidikan akhlak remaja masih sangat kurang, pemahamaan orang tua tentang ilmu agama islam masih minim sehingga pendidikan ahklak remaja dalam rumah tangga atau keluarga muslim sangat terbatas dan Konsep pendidikan keluarga terhadap remaja dalam pendidikan akhlak adalah memberikan keteladanan dan memberikan pengetahuan kegamaan secara inensif kepada remaja secara individu dirumah.
\end{abstract}

Kata Kunci: Pendidikan Akhlak, Remaja, Keluarga Muslim, Era Industri 4.0.

\title{
Pendahuluan
}

Keberlangsuan suatu bangsa dan negara ditentukan oleh bagaimana sumber daya manusia yang dimiliki oleh dibina dan dididik untuk menerima setafet kepemimpinan berikutnya. Pendidikan sebagai salah satu bentuk usaha pembinaan mesti dibangun dengan peneuh keseriusan. Pendidikan sesungguhnya merupakan pembibitan generasi penerus yaitu persemaian tunas bangsa yang pada waktunya akan ditebarkan dalam masyarakat sebagai pemegang tongkat tanggung jawab dalam membangun bangsa dan negara. sebagai usaha sadar terencana, terorganisir, yang diberikan oleh manusia dewasa kepada seorang anak yang berupa bimbingan pengajaran dan atau latihan yang akan berdampak bagi perananya dalam bermasyarakat, berbangsa, dan bernegara yang mencakup pertumbuhan jasmani dan rohani seorang anak (siswa). Oleh karena itu pendidikan menjadi bagian terpenting dalam kehidupan berbangsa yang harus ditangani dan menjadi tugas bersama, mulai dari pemerintah maupun swasta, dari pejabat hingga rakyat, hingga keluarga sebagai bagian dari masyarakat.

Terkait dengan itu, tujuan pendidikan mesti dirumuskan untuk pembinaan dan pembentukan akhlak bagi peserta didik. Mengapa harus akhlak yang diutamakan?, hal ini karena akhlak merupakan pedoman hidup yang dapat membedakan antara manusia dengan makhluk Allah yang lain. jika manusia tidak berakhlak maka akan hilanglah derajat kemanusiaanya sebagai makhluk Allah yang paling mulia, bahkan lebih hina dibandingkan hewan sekalipun, karena manusia 
akan terlepas dari kendali nilai-nilai yang seharusnya menjadi pegangan dan pedoman menjalani kehidupan.

Melihat konteks tersebut, maka pendidikan akhlak harus merupakan prioritas utama dalam pendidikan dan mutlak untuk selalu diusahakan baik melalui jalur pendidikan formal maupun non formal dari keluarga. Bahkan lebih dari sekedar itu, jatuh bangunnya, jaya hancurnya, sejahtera rusaknya suatu bangsa sangat bergantung kepada bagaimana akhlak dari generasi penerusnya yang dipegang oleh para remaja saat ini, apabila akhlaknya baik (berakhlak), akan sejahteralah lahir batinnya, akan tetapi apabila akhlaknya buruk (tidak berakhlak), rusaklah lahir dan batinnya.

Disamping peranan pendidikan sekolah/madrasah yang menjadi dasar dalam pembentukan kepribadian anak, orang tua/keluarga juga memegang peran yang penting dalam pembentukan kepribadian anak-anak baik buruknya kepribadian anak-anak-di masa yang akan datang banyak ditentukan oleh pendidikan agama dan bimbingan orang tua. sebelum seseorang menerima pendidikan dari yang lain, lingkungan keluarga menjadi tempat dimana anak-anak pertama kali memperoleh pendidikan karena keluarga adalah madrasatul ula. Segala bentu aktifitas anggota keluarga terutama orang tua akan menjadi suri tauladan oleh anak-anaknya. Oleh karena itu, orang tua harus selalu memberikan contoh suri tauladan yang baik bagi anak-anak mereka, karena apapun kebiasaan orang tua dirumah akan selalu dilihat dicerna dan bahkan sampai akan ditiru oleh anak-anak karena pendidikan di dalam keluarga berjalan sepanjang masa, melalui proses interaksi dan sosialisasi dalam keluarga itu sendiri. ${ }^{1}$

Penilaian terhadap baik dan buruknya pribadi manusia itu sangat ditentukan oleh lingkungan yang ada di sekitarnya, tidak hanya lingkungan saja bahkan teman, orang tua, guru maupun masyarakat dan juga pendidikan yang ditanamkan sejak kecil dalam kehidupan sehari-harinya. Pembiasaan-pembiasaan anak terhadap sikap dan perilaku terpuji atau perbuatan baik harus dibiasakan sejak kecil, sehingga lama-kelamaan akan tumbuh rasa senang melakukan perbuatan yang baik tersebut. Dia dibiasakan sedemikian rupa sehingga dengan sendirinya akan terdorong untuk melakukannya, tanpa perintah dari luar, tapi dorongan dari dalam. "Seperti prinsip agama Islam, tapi ada keharusan pendidikan yang dibebankan kepada orang tua dan guru atau orang yang mengerti agama (ulama').

\footnotetext{
1 Nurmaidah. Peranan pendidikan agama dalam keluarga terhadap pembentukan kepribadian anak-anak. (Jurnal Al-afkar 2013).
}

Dirasah, Vol. 3, No. 1, Februari 2020 
Jadi berpijak pada paparan tersebut melahirkan pertanyaan bagaimana peran orang tua dan strategi meningkatkan pendidikan akhlak pada remaja dalam keluarga muslim di era industri 4.0, mengingat pendidikan remaja adalah titik penting dalam membentuk keberhasilan pendidikan remaja dimasa-masa selanjutnya saat remaja menjadi dewasa. Jenis penggolongan penelitian ini adalah penelitian kualitatif deskriptif.

\section{Pembahasan}

\section{Konsep Pendidikan akhlak}

Kata Pendidikan dalam bahasa Yunani berasal dari kata padegogik yaitu ilmu menuntun anak. Orang Romawi melihat pendidikan sebagai educare, yaitu mengeluarkan dan menuntun, tindakan merealisasikan potensi anak yang dibawa waktu dilahirkan di dunia. Bangsa Jerman melihat pendidikan sebagai Erziehung yang setara dengan educare, yakni: membangkitkan kekuatan terpendam atau mengaktifkan kekuatan atau potensi anak.

Dalam bahasa Jawa, pendidikan berarti panggula wentah (pengolahan), mengolah, mengubah kejiwaan, mematangkan perasaan, pikiran, kemauan dan watak, mengubah kepribadian sang anak. Dalam Kamus Besar Bahasa Indonesia (KBBI) pendidikan berasal dari kata dasar didik (mendidik), yaitu memelihara dan memberi latihan (ajaran, pimpinan) mengenai akhlak dan kecerdasan pikiran. pendidikan mempunyai pengertian proses pengubahan sikap dan tata laku seseorang atau kelompok orang dalam usaha mendewasakan manusia melalui upaya pengajaran dan latihan, proses perbuatan, cara mendidik.

Menurut Ki Hajar Dewantara mengartikan pendidikan sebagai daya upaya untuk memajukan budi pekerti, pikiran serta jasmani anak, agar dapat memajukan kesempurnaan hidup yaitu hidup dan menghidupkan anak yang selaras dengan alam dan masyarakatnya. Secara lebih filosofis Muhammad Natsir dalam tulisan "Idiologi Pendidikan Islam" menyatakan : "Yang dinamakan pendidikan, ialah suatu pimpinan jasmani dan ruhani menuju kesempurnaan dan kelengkapan arti kemanusiaan dengan arti sesungguhnya.

Sedangkan Menurut Abdur Rahman an-Nahlawi tentang konsep Tarbiyah (pendidikan) dalam empat unsur :

1. Memelihara pertumbuhan fitrah manusia.

2. Mengarahkan perkembangan fitrah manusia menuju kesempurnaan.

3. Mengembangkan potensi insani (sumber daya manusia) untuk mencapai kualitas tertentu. 
4. Melaksanakan usaha-usaha tersebut secara bertahap sesuai dengan irama perkembangan anak. ${ }^{2}$

Akhlak seorang anak-anak sangat ditentukan oleh pendidikan yang mereka peroleh sejak kecil yang dimulai dari lingkungan keluarga. Oleh karena orang tua bertanggung jawab penuh terhadap pelaksanaan pendidikan anak. Kemapuan seorang anak dalam mengembangkan potensi dasar yang kelak akan sangat berguna di masyarakat, bangsa negara dan agama sangat dipengaruhi peran orang tua dalam mengasuh dan mendidik anaknya. ${ }^{3}$. Disamping peranan pendidikan yang menjadi dasar dalam pembentukan kepribadian anak. Orang tua juga memegang peran yang penting membentuk kepribadian anak-anak yang salah satunya melalui pendidikan agama dan bimbingan orang tuanya. Pendidikan yang diberikan di lingkungan keluarga berbeda dengan pendidikan yang diberikan di sekolah, karena pendidikan dilingkungan keluarga bersifat informal. Maka dari itu, hak anak untuk memperoleh pendidikan akhlak harus diperhatikan para orang tua. Pembinaan dan pendidikan akhlak harus ditanamkan sejak usia kandungan. Era industri 4.0 ditandai dengan kemajuan di bidang teknologi informasi. Permasalahannya sekarang adalah dengan kemajuan di bidang teknologi informasi tersebut, mau tidak mau, suka tidak suka, akan berpengaruh terhadap pertumbuhan anak. Karena itu, sebagai orang tua harus turut serta mengontrol dan mengawasi putra putrinya bila berhadapan dalam dunia maya. Selain pengawasan yang intensif, penananam akhlak sejak dini juga harus dilakukan, kalau kita tidak ingin kecolongan. ${ }^{4}$

Dapat penulis simpulkan tentang pendidikan, bahwasanya pendidikan adalah usaha sadar untuk Mendewasakan diri melalui pengajaran,dan pelatihan untuk mencapai sebuah tujuan pendidikan dan agar menjadi insan yang kamil yang berakhlakul kharimah. Dan Tujuan pendidikan adalah menjadikan anak mengembangkan potensinya.

\section{Akhlak Remaja}

Akhlak (akhlaq) secara etimologi adalah bentuk jamak dari khuluq yang berarti budi pekerti, perangai, tingkah laku atau tabiat. Berakar dari kata khalaqa

\footnotetext{
${ }^{2}$ Nurkholis, Pendidikan Dalam Upaya Memajukan Teknologi. (Jurnal Kependidikan, 2013)

3 Hernawati. Peranan orang tua terhadap pembinaan akhlak peserta didik MI Poli Mandar. Auladuna( Jurnal Penelitian dasar Islam, 2016)

${ }^{4}$ Siti Zulaikha, urgensi pembinaan akhlak bagi anak anak prasekolah. Edukasia: (Jurnal penelitian Pendidikan Islam 2018)
}

Dirasah, Vol. 3, No. 1, Februari 2020 
yang berarti menciptakan. Seakar dengan kata khaliq (Pencipta), makhluq (yang diciptakan) dan khalq (penciptaan).

Menurut Abdullah Daraz, perbuatan- perbuatan manusia dapat dianggap sebagai akhlak apabila memenuhi dua syarat sebagai berikut: pertama, perbuatanperbuatan itu dilakukan berulangkali sehingga perbuatan-perbuatan itu menjadi kebiasaan; kedua, perbuatan-perbuatan itu dilakukan dengan kehendak sendiri bukan karena adanya tekanan-tekanan yang datang dari luar seperti ancaman dan paksaan atau sebaliknya melalui bujukan dan rayuan.

Menurut Al-Ghazali memaknai akhlak dengan Sebuah tatanan yang tertanam kuat dalam jiwa yang darinya muncul beragam perbuatan dengan mudah dan ringan, tanpa membutuhkan pemikiran dan pertimbangan. Sebagian lagi mendefinisikan akhlak dengan Sekumpulan nilai-nilai dan sifat yang menetap di dalam jiwa, yang dengan petunjuk dan standarnya sebuah perbuatan dinilai baik atau buruk oleh seseorang, yang untuk kemudian dia melakukan perbuatan tersebut atau mengurungkannya. ${ }^{5}$

Dalam konteks ini, akhlak merupakan sifat yang tertanam dalam jiwa, yang dengannya lahirlah macam-macam perbuatan, baik dan buruk, tanpa membutuhkan pemikiran dan pertimbangan". Ini juga bisa diartikan bahwa akhlak adalah tabiat atau pola interaksi seorang hamba terhadap Tuhan dan manusia yang dikenal dengan nama ihsan.

Kata "remaja" berasal dari bahasa latin yaitu adolescere yang berarti to grow atau to grow maturity. Banyak tokoh yang memberikan definisi tentang remaja, seperti DeBrun, mendefinisikan "remaja sebagai periode pertumbuhan antara masa kanak-kanak dengan masa dewasa". Banyak pertumbuhan antara masa kanakkanak dan dewasa.

Papila dan Olds, tidak memberikan pengertian remaja secara eksplisit melainkan secara implisit melalui pengertian masa remaja. Masa remaja adalah masa transisi perkembangan antara masa kanak-kanak dan dewasa pada umumnya dimulai pada usia 12 atau 13 tahun dan berakhir usia akhir belasan atau dua puluh tahun. Sedangkan Anna freud berpendapat bahwa pada Masa remaja terjadi proses perkembangan meliputi perubahan-perubahan yang berhubungan dengan perkembangan psikoseksual dan juga terjadi perubahan dalam hubungan dengan

\footnotetext{
${ }^{5}$ Ibrahim Bafadhol, 2017. Pendidikan Akhlak Dalam Perspekstif Islam. (Jurnal Edukasi Islami Jurnal Pendidikan Islam 2017)
}

Dirasah, Vol. 3, No. 1, Februari 2020 
orang tua dan cita-cita mereka, dimana pembentukan cita-cita merupakan proses pembentukan orientasi masa depan. ${ }^{6}$

Masa remaja (remaja awal dan remaja akhir) adalah masa yang penuh emosi secara psikologis, Masa ini ditandai dengan kondisi jiwa yang labil, tidak menentu dan biasanya susah mengendalikan diri sehingga pengaruh-pengaruh negatif seperti perilaku-perilaku menyimpang akibat dari pergeseran nilai mudah mempengaruhi jiwa remaja dan menimbulkan gejala baru berupa krisis akhlak di kalangan generasi remaja. Perkembangan global dan kemajuan iptek yang tidak diimbangi dengan kemajuan moral akhlak menjadi salah satu faktor pesatnya kemerosotan akhlak yang dialami para remaja. Indicator ini dapat dilihat diantaranya sikap dan perilaku remaja yang cenderung lekas marah, kurang hormat terhadap orang tua, bersikap kasar, kurang disiplin dalam beribadah, menjadi pemakai obat-obatan, pemakai narkoba dan seks bebas. Kemerosotan/krisis akhlak ini menjadi pekerjaan rumah bagi semua kalangan. Baik dan buruknya remaja dimasa yang akan dating akan sangat ditentukan oleh generasi saat ini yang menjadi pembimbing dan pendidi mereka. Sebagaimana dikatakan dalam teori yang menjelaskan pada dasarnya seorang anak dilahir ke dunia itu suci bagaikan kertas putih yang belum tertulisi tinta, dan akan menjadi apakah bayi itu dikemudian hari, tergantung kepada apa dan siapa yang akan menuliskannya.

Pendidikan akhlak remaja bertujuan untuk terwujudnya sikap batin yang mampu mendorong melakukan perbuatan yang bernilai baik atau pribadi susila, sehingga akan memperoleh kebahagiaan di sisi Allah di akhirat kelak dan hidup dengan perilaku yang baik di dunia. Dengan begitu diharapkan akan diperoleh kebahagiaan (al-sa'adah). Dalam mewujudkan sikap batin yang mampu mendorong perbuatan yang bernilai baik. dan

Ibn 'Arabi mengemukakan bahwa penanaman dan pembentukan akhlak dalam diri manusia bisa terjadi, karena di dalam bentuk manusia (al-surah alinsaniyah) telah terdapat nama-nama Tuhan (al-asma' al-ilahiyah) dan hubunganhubungan Tuhan (al-nisab al-rabbaniyah). Itulah mengapa di dalam diri manusia terdapat akhlak yang sudah terpateri di dalamnya. Mengambil dan menerapkan akhlak Tuhan, yakni nama-nama Tuhan, akan menghasilkan pengetahuanpengetahuan tentang Tuhan (al-ma'arif al-ilahiyah). ${ }^{7}$

\footnotetext{
${ }^{6}$ Yahya, Yudrik. Psikologi perkembangan. (Jakarta: Kencana 2011)

${ }^{7}$ Payis Zawahir, Muntaha dan Ismail Suardi wekke. Pendidikan akhlak remaja bagi keluarga kelas menengah perkotaan. ( Cendekia 2017)
}

Dirasah, Vol. 3, No. 1, Februari 2020 
Dari penjelasan di atas kiranya dapat penulis simpulkan bahwa akhlak Remaja adalah suatu sikap, perilaku, tingkah laku yang dimiliki seorang remaja yang mampu melakukan perbuatan yang baik agar tidak melakukan hal-hal yang menyimpang.

\section{Keluarga Muslim}

Keluarga secara etimologis berasal dari rangkaian kata "kawu- la" dan "warga". kawula artinya abdi yakni hamba, sedangkan warga artinya anggota. Sebagai abdi didalam keluarga, seorang wajib me- nyerahkan segala kepentingannya kepada keluarganya dan warga atau anggota. Ia berhak untuk ikut mengurus segala kepentingan di dalam keluarganya.

Dalam ensiklopedi umum yang dimaksud dengan keluarga yaitu kelompok orang yang ada hubungan darah atau perkawinan yang terdiri dari ibu, ayah, anakanaknya ( yang belum memisahkan diri sebagai keluarga). Dalam bahasa Inggris kata keluarga di artikan dengan family. Everet wilson mengartikan family (keluarga) adalah "the face to face group" (kelompok tatap muka). Dia mengartikan lebih ke arah fungsi keluarga.

Menurut M. I Sulaiman, ciri hakiki suatu keluarga adalah bahwa keluarga itu merupakan: "satu persekutuan hidup yang dijalin kasih sayang antara pasangan dua jenis manusia yang dikukuhkan dengan pernikahan, yang bermaksud untuk saling me nyempurnakan diri". Sedangkan Menurut Syamsu Yusuf, keluarga dipandang sebagai penentu utama pembentukan kepribadian anak. Alasannya adalah:

1. Keluarga merupakan kelompok sosial pertama yang menjadi pusat indentifikasi anak.

2. Anak banyak menghabiskan waktunya di lingkungan keluarga.

3. para anggota keluarga merupakan "signifi- cant people" bagi pembentukan kepribadian anak.

Menurut M.I. Sulaiman, fungsi keluarga itu ada delapan jenis yaitu: fungsi edukasi, fungsi sosialisasi, fungsi proteksi, fungsi afeksi, fungsi religius, fungsi ekonomi, fungsi rekreasi, dan fungsi biologis. ${ }^{8}$

Anggota keluarga sebagai orang terdekat merupakan faktor utama untuk membantu para remaja menghadapi kemerosotan/krisis akhlak sebagaimana yang dikemukakan diatas. Pendidikan akhlak berupa bimbingan, arahan, nasehat, disiplin yang berlandaskan nilai-nilai ajaran agama Islam harus senantiasa selalu

\footnotetext{
${ }^{8}$ Nurmaidah. Peranan pendidikan agama dalam keluarga terhadap pembentukan kepribadian anak-anak. ( Jurnal Al-afkar 2013)
} 
ditanamkan dan dikembangkan orang tua terhadap para remaja dalam kehidupan keluarga. Keluarga adalah komunitas terkecil sebagai salah satu pilar penentu baik atau buruknya dalam sebuah kelompok masyarakat. Kebaikan dan keburukan sebuah komunitas masyarakat dapat diukur dengan meninjau kondisi keluarga karena keluarga inilah tempat dimana ditanamkan, terpupuk, dan dikembangkan embrio nilai-niai akhlak kemasyarakatan Islam memberikan sebuah konsep, pendidikan anak merupakan tanggung jawab kedua orang tua.

Menurut husnawati, baik bapak maupun ibu memiliki beban tanggung jawab yang sama terhadap pendidikan akhlak anak-anak mereka. Sedangkan menurut Kadir, bahwa Keluarga mempunyai peranan penting dalam membentuk generasi muda. Keluarga disebut pula sebagai lembaga pendidikan informal dimana kegiatan pendidikan yang ada tidak selalu diorganisasikan secara struktural. Pada umumnya pendidikan dalam rumah tangga itu bukan berpangkal tolak dari kesadaran dan pengertian yang lahir dari pengetahuan mendidik, melainkan karena secara kodrati suasana dan strukturnya, dan Situasi pendidikan itu terwujud berkat adanya perpaduan dan hubungan pengaruh memengaruhi secara timbal balik antara orang tua dan anak. Sebagai lingkungan pendidikan yang pertama, keluarga memegang peran yang sangat besar dalam membentuk pola kepribadian anak. Oleh karena itu orang tua sebagai penanggung jawab atas kehidupan keluarga harus memberikan pendidikan dan pengajaran kepada anak-anaknya dengan menanamkan pendidikan agama dan akhlak yang baik dalam kehidupan sehari-hari. Sebagai orang tua dituntut untuk memberikan pembinaan akhlak yang mulia terhadap anak. Kemudian yang memberikan pendidikan yang pertama dan utama adalah orang tua.

Dari beberapa pendapat diatas penulis Simpulkan bahwa keluarga merupakan pendidik dan pendidikan yang pertama dan yang utama yang diperoleh anak dari kandungan hingga lahir sebelum mengenal pendidikan sekolah.

\section{Era Industri 4.0}

Sejarah revolusi industri dimulai dari industri 1.0 hingga industri 4.0. Fase industri dari masa ke masa adalah real change dari perubahan yang ada. Era industri 1.0 sebagai awal perubahan dengan mekanisasi produksi untuk menunjang efektifitas dan efisiensi kerja manusia, produksi massal dan standarisasi mutu menjadi tanda dimulaintya era industri 2.0, sedangkan ciri era industri 3.0 ditandai dengan penyesuaian massal dan fleksibilitas manufaktur berbasis otomasi dan robot. Selanjutnya yang paling terkini hadirlah era Industri 4.0 sebagai penerus dari 
era-era industry sebelumnya ditandai dengan kolaborasi manufaktur dan cyber fisik. Istilah industri 4.0 berasal dari sebuah proyek yang diprakarsai oleh pemerintah Jerman untuk mempromosikan komputerisasi manufaktur.

Hermann et al menambahkan, ada empat desain prinsip industri 4.0. Pertama, interkoneksi (sambungan) yaitu kemampuan mesin, perangkat, sensor, dan orang untuk terhubung dan berkomunikasi satu sama lain melalui Internet of Things (IoT) atau Internet of People (IoP). Prinsip ini membutuhkan kolaborasi, keamanan, dan standar. Kedua, transparansi informasi merupakan kemampuan sistem informasi untuk menciptakan salinan virtual dunia fisik dengan memperkaya model digital dengan data sensor termasuk analisis data dan penyediaan informasi. Ketiga, bantuan teknis yang meliputi;(a) kemampuan sistem bantuan untuk mendukung manusia dengan menggabungkan dan mengevaluasi informasi secara sadar untuk membuat keputusan yang tepat dan memecahkan masalah mendesak dalam waktu singkat; (b) kemampuan sistem untuk mendukung manusia dengan melakukan berbagai tugas yang tidak menyenangkan, terlalu melelahkan, atau tidak aman; (c) meliputi bantuan visual dan fisik. Keempat, keputusan terdesentralisasi yang merupakan kemampuan sistem fisik maya untuk membuat keputusan sendiri dan menjalankan tugas seefektif mungkin. Secara sederhana, prinsip industri 4.0 menurut Hermann et al dapat digambarkan sebagai berikut. Industri 4.0 telah memperkenalkan teknologi produksi massal yang fleksibel. Mesin akan beroperasi secara independen atau berkoordinasi dengan manusia. Industri 4.0 merupakan sebuah pendekatan untuk mengontrol proses produksi dengan melakukan sinkronisasi waktu dengan melakukan penyatuan dan penyesuaian produksi. Selanjutnya, Zesulka et al menambahkan, industri 4.0 digunakan pada tiga faktor yang saling terkait yaitu; 1) digitalisasi dan interaksi ekonomi dengan teknik sederhana menuju jaringan ekonomi dengan teknik kompleks; 2) digitalisasi produk dan layanan; dan 3) model pasar baru.

Revolusi digital dan era disrupsi teknologi adalah istilah lain dari industri 4.0. Disebut revolusi digital karena terjadinya proliferasi komputer dan otomatisasi pencatatan di semua bidang. Industri 4.0 dikatakan era disrupsi teknologi karena otomatisasi dan konektivitas di sebuah bidang akan membuat pergerakan dunia industri dan persaingan kerja menjadi tidak linear. Salah satu karakteristik unik dari industri 4.0 adalah pengaplikasian kecerdasan buatan atau artificial intelligence. Salah satu bentuk pengaplikasian tersebut adalah penggunaan robot untuk menggantikan tenaga manusia sehingga lebih murah, efektif, dan efisien. Kemajuan teknologi memungkinkan terjadinya otomatisasi hampir di semua 
bidang. Teknologi dan pendekatan baru yang menggabungkan dunia fisik, digital, dan biologi secara fundamental akan mengubah pola hidup dan interaksi manusia.

\section{Peran Orang tua dan Strategi Dalam meningkatkan pendidikan akhlak pada remaja dalam keluarga Muslim Di Era Industri 4.0 .}

Penulis menggunakan metode penelitian dalam menemukan informasi tentang konsep pendidikan akhlak remaja dalam keluarga muslim di Era Industri 4.0, dengan menggunkan metode, observasi, wawancara, dan dokumentasi. Maka dalam hal ini penulis ingin membahas hasil penelitian tentang Peranan orang tua terhadap pendidikan akhlak dalam Keluarga Muslim Di Era Industri 4.0, perlu peneliti bahas sebab melihat kenyataan yang terjadi bahwa masyarakat lingkungan Dalam Keluarga Muslim Di Era Industri 4.0 yang pada dasarnya mayoritas Islam tetapi tingkat pemahaman tentang agama Islam masih kurang. Sehingga untuk pengembangan sumber daya manusia (SDM) yang utama harus diprioritaskan adalah pengetahuan tentang agama Islam yang mana harus merupakan pondasi awal yang harus dibekali kepada anak.

Sebagian orang tua peserta didik lebih sibuk dengan pekerjaannya diluar rumah ada pula beberapa peserta didik yang tidak tinggal bersama orang tuanya karena faktor inilah sehingga peserta didik itu sendiri kurang dalam didikan dirumah, perhatian dan kasih sayang dari orang tuanya tidak dia dapatkan yang semestinya menjadi tanggung jawab ayah dan ibunya. orang tua ayah dan ibu tidak memiliki banyak waktu untuk anaknya sehingga anak yang membutuhkan perhatian dari orang tuanya mencarinya kepada orang lain yang bisa anak akan melakukan perilaku menyimpang.

Fakta yang sudah peneliti dapat disimpulkan, bahwa melihat keadaan masyarakat di lingkungan Keluarga yang mana pemahaman Orang tua tentang Agama Islam masih sangat kurang, tingkat pengetahuan tentang agama Islam masih sangat minim, baik dari segi hubungan kepada Allah maupun hubungan kepada manusia. Contohnya: pada saat di rumah, remaja tidak mendapatkan bimbingan kerohanian seperti bimbingan sholat, karena orang tuanya ada, karena orang tuanya sibuk bekerja di dunia luar. Pada saat di sekolah, remaja sering kali tidak mendengarkan gurunya pada saat pelajaran sedang berlangsung, dan pada saat di lingkungan masyarakat remaja sering kali tidak menghargai teman sebayanya serta tidak bersikap dan berperilaku sopan terhadap orang yang lebih tua darinya. karena orang tuanya hanya sibuk mencari nafkah lahiriyah anaknya tanpa memikirkan nafkah batiniyahnya. Hal yang seperti ini jika tidak ada penanganan akan menjadikan Remaja tidak menghormati norma-norma yang ada, Remaja tidak 
akan patuh kepada agamanya, mengabaikan nasihat orang tuanya dan akan berdampak terhadap pergaulannya di masyarakat. ${ }^{9}$

Strategi Dalam meningkatkan pendidikan akhlak pada remaja dalam keluarga Muslim Di Era Industri 4.0 .

Upaya atau strategi untuk meningkatkan pendidikan akhlak pada remaja dalam keluarga muslim di Era Industri 4.0 lebih ditekankan pada kualitas pendidikan agama islam yaitu meliputi:

1. Mengenal Allah dan ciptaannya guna mempertebal iman dan keyakinannya. Dengan kekuatan iman yang berdasarkan tauhid, para remaja mempunyai kekuatan batin yang tangguh dalam menghadapi tantangan, cobaan dan godaan hidup.

2. Mengenal diri dan lingkungannya. Menghayati makna dan tujuan hidup serta mengetahui jalan kehidupan yang baik yang diridhoi oleh Allah dan membawa keselamatan dan kebahagiaan hidup serta terhindar dari perbuatan yang tercela yang membawa akibat buruk bagi kehidupan dirinya dan masyarakat lingkungannya.

Memelihara hubungan dengan Allah, memelihara hubungan dengan manusia dalam tatanan hidup bermasyarakat dan berbangsa, memelihara hubungan dengan alam lingkungan. Dengan memelihara ketiga hubungan tersebut, para remaja dapat memelihara kesucian dan keutuhan dirinya serta keseimbangan hidup antara kehidupan fisik materiil dan mental spiritual, kehidupan jasmani dan rohani, kehidupan jiwa dan raga, serta kehidupan dunia dan akhirat.

3. Mengetahui, memahami dan menghayati nilai-nilai dan norma-norma baik dan buruk, benar dan salah, serta batas-batas mana yang boleh dan mana yang tidak boleh. Dengan mengetahui, memahami, dan menghayati nilai-nilai dan normanorma tersebut, para remaja akan menjaga dirinya agar selalu hidup di jalan yang benar, jalan yang di Ridhoi oleh Allah SWT.

Strategi adalah jantung dari tiap keputusan yang diambil kini dan menyangkut masa depan. Tiap strategi selalu dikaitkan dengan upaya mencapai sesuatu tujuan di masa depan, yang dekat maupun yang jauh. Tanpa tujuan yang ingin diraih, tidak perlu disusun strategi. Selanjutnya, suatu strategi hanya dapat disusun jika terdapat minimal dua pilihan. Tanpa itu, orang cukup menempuh satusatunya alternatif yang ada dan dapat digali.

9 Hernawati. Peranan orang tua terhadap pembinaan akhlak peserta didik MI Poli Mandar. (Auladuna: Jurnal Penelitian dasar Islam 2016) 
Salah satu strategi adalah bimbingan dari keluarga. Pembimbingan yang pertama diberikan di lingkungan keluarga, karena keluarga adalah lingkungan hidup pertama, dimana anak memperoleh pengalaman-pengalaman pertama yang telah mempengaruhi jalan hidupnya. jadi lingkungan pertama yang memberi tantangan pada anak supaya tidak dapat menyelesaikan terhadap lingkungan hidupnya. Untuk mencapai interaksi yang baik antara orang tua dengan anakanaknya maka dalam keluarga itu harus menjalankan peranannya sesuai dengan fungsi dan kedudukannya, baik di dalam keluarga itu sendiri maupun di lingkungan masyarakat.

\section{Kesimpulan}

Peranan orang tua terhadap pendidikan akhlak dalam Keluarga Muslim Di Era Industri 4.0, melihat kenyataan yang terjadi bahwa masyarakat lingkungan Dalam Keluarga Muslim Di Era Industri 4.0 yang pada dasarnya mayoritas Islam tetapi tingkat pemahaman tentang agama Islam masih kurang. Sehingga untuk pengembangan sumber daya manusia (SDM) yang utama harus diprioritaskan adalah pengetahuan tentang agama Islam yang mana harus merupakan pondasi awal yang harus dibekali kepada anak. Keluarga yang mana pemahaman Orang tua tentang Agama Islam masih sangat kurang, tingkat pengetahuan tentang agama Islam masih sangat minim, baik dari segi hubungan kepada Allah maupun hubungan kepada manusia. Sedangkan Upaya atau strategi untuk meningkatkan pendidikan akhlak pada remaja dalam keluarga muslim di Era Industri 4.0 adalah dengan mengenalkan Allah dengan mempertebal Iman dan keyakinan, mengenal diri dan lingkungan, memelihara hubungan dengan Allah dan Mengetahui, memahami dan menghayati nilai-nilai dan norma-norma baik dan buruk, benar dan salah, serta batas-batas mana yang boleh dan mana yang tidak boleh.

\section{Daftar Pustaka}

Bafadhol, Ibrahim. Pendidikan Akhlak Dalam Perspekstif Islam. Jurnal Edukasi Islami Jurnal Pendidikan Islam. 2017.

Depdiknas RI. Kamus BesarBahasa Indonesia. Jakarta: Pusat Bahasa. 2008.

Hernawati. Peranan orang tua terhadap pembinaan akhlak peserta didik MI Poli Mandar. Auladuna: Jurnal Penelitian dasar Islam. 2016.

Madjid, Nurcholis. Islam Kemodernan dan Keindonesiaan. Bandung: Mizan. 1997. Nurkholis. Pendidikan Dalam Upaya Memajukan Teknologi. Jurnal Kependidikan. 2013.

Dirasah, Vol. 3, No. 1, Februari 2020 
Nurmaidah. Peranan pendidikan agama dalam keluarga terhadap pembentukan kepribadian anak-anak. Jurnal Al-afkar. 2013.

Trianto. Mendesain Model Pembelajaran Inovatif-Progresif. Jakarta: Kencana Prenada Media Group. 2013.

Undang-undang Nomor 20 Tahun 2003 Tntang Sistem Pendidikan Nasional

Yahya, Yudrik. Psikologi perkembangan. Jakarta: Kencana. 2011.

Zawahir, Payiz. Muntaha dan Ismail Suardi wekke. Pendidikan akhlak remaja bagi keluarga kelas menengah perkotaan. Cendekia. 2017.

Zulaikha, Siti. urgensi pembinaan akhlak bagi anak anak prasekolah. Edukasia: Jurnal penelitian Pendidikan Islam. 2013.

Copyright (C 2020 Journal Dirasah: Vol. 3, No. 1, Februari 2020, p-ISSN: 2615-0212, e-ISSN;

2621-2838

Copyright rests with the authors

Copyright of Jurnal Dirasah is the property of Jurnal Dirasah and its content may not be copied oremailed to multiple sites or posted to a listserv without the copyright holder's express writtenpermission. However, users may print, download, or email articles for individual use.

https://ejournal.iaifa.ac.id/index.php/dirasah

Dirasah, Vol. 3, No. 1, Februari 2020 